\title{
Performance of General Elections Commission in Increasing Public Participation in 2015
}

\author{
Rossy Lambelanova \\ Lembaga Administrasi Negara \\ Jatinangor, Jawa Barat, Indonesia \\ rossylambelanova@gmail.com
}

\author{
Elok Mufidatut Tarwiyah \\ Lembaga Administrasi Negara \\ Jatinangor, Jawa Barat, Indonesia \\ eltarwiyah@gmail.com
}

\begin{abstract}
Direct Local Elections plays strategic role in the progress of democratic life at local political level. This study was aimed to examine and analyze the performance of KomisiPemilihanUmum (KPU) (General Elections Commission) in increasing public participation in 2015 Local Elections of Blitar regency. The problems were lack of human resources in $K P U$ of Blitar regency, and low public participation due to factors such as economic, domicile, and public awareness. Performance theory by Mahsun as for the grounding theory. The object of study was $K P U$ of Blitar regency, while the approach used was qualitative with interview method. Secondary data from literature study on relevant scientific references was used to support analysis of primary data. The result showed that performance of $K P U$ of Blitar regency was not optimal, KPU still underwent some problems to increase public participation, in terms of the indicators of input, process, outcome, and impact.
\end{abstract}

\section{Keywords-Performance; Public Participation; Democracy}

\section{INTRODUCTION}

Komisi Pemilihan Umum (KPU)(General Elections Commission) is the state institution that organize elections in Indonesia, including legislative elections, presidential elections, and local elections.

Law No. 8 of 2015 on Amendment of Law No. 1 of 2015 on Decision of Government Regulation in Lieu of Law No. 1 of 2014 on Governor, Regent, and Mayoral Elections as Law is one of consequences given by central government for Indonesian citizens with sovereignty to implement the bureuacracy of Indonesian government, who adopt direct local electoral system to vote a candidate pair nominated by a political party or collaboration of political parties. Indonesian citizens who are qualified in Daftar Pemilih Tetap (DPT)(Final Voter List) possess the right to vote under the democratic principles of direct, general, free, confidential, honest, and fair. The Law regulates the implementation of simultaneous local elections by $K P U$ that once were held in December 9, 2015 in 8 provinces, 170 regencies, and 26 cities. The $K P U$ shall have national, permanent, and independent characteristics in holding general elections.

Unfortunately, the fact was that there were problems in implementation of the simultaneous local elections, especially in Blitar regency, regarding the human resources within the
$K P U$ of Blitar regency, knowledge on the implementation, territorial situation, and also public participation. This is what made the implementation of local elections in Blitar regency not in line with the spirit of democracy, namely the high proportion of voters in DPT who didn't attend the voting process, or more known as absentee (golongan putih (golput)).

According to data from $K P U$ of Blitar regency, number of voters in DPT and additional voters in election of Regent and Vice-Regent in December 9, 2015 was 967,463, while number of vote cast was only 545,477 thus making number of absentee voters was 421,986 or equal to $43.61 \%$. This phenomenon suggests that public participation in the 2015 Election of Regent and Vice-Regent of Blitar Regency was similar to previous election in 2010 with number of absentee voters by $44.3 \%$. With total number of voters by $55.7 \%$, it can be concluded that public participation rate in Blitar regency is low. The parameter used was derived from survey organization of $K P U$, showing that the public participation rate in simultaneous local elections nationally in 2015 was $64.02 \%$, lower from targeted rate by $77.5 \%$. Public participation in Blitar regency was even lower than national public participation rate.

With only one candidate pair in the local election, Drs. $\mathrm{H}$. Rijanto, M.M. and Marhaennis Urip Widodo, S.Sos., where the regent candidate was an incumbent candidate (which in previous period was the Vice-Regent), it was considered as one of causes for the low rate of public participation. Covered by tempo.co dated December 14, 2015, one of citizens of Blitar regency argued that sole candidate, people was not provided with other options for their next leader. In addition, more people chose to go farming due to rainy season rather than attended the polling station to vote, and many residents were away from their voting residence of Blitar Regency due to work or education reasons.

Based on background elaborated above, the problem statement specifically for this study as the research question was: How was the performance of $K P U$ in increasing public participation in 2015 Local Elections of Blitar regency, East Java Province?

This study was aimed to examine and analyze the performance of $K P U$ in increasing public participation in 2015 Local Elections of Blitar regency. 


\section{RESEARCH METHOD}

Method used here was qualitative descriptive. Moleong (2010: 6) asserts that "qualitative research is research aimed to understand the phenomenon of what is experienced by the subject, such as behavior, perception, action, etc.". Source of data was derived from primary data obtained by interviewing informants (Sugiyono, 2013: 137), and secondary data obtained by reviewing the reading materials and other literature related to focus of the research. For data analysis, Miles and Huberman's (1992: 17) asserts that activities in data analysis are data reduction, data display, and data conclusion drawing/verification.

\section{DISCUSSION}

In this research, Mahsun's (2012: 77) argument was used as analysis tool to elaborate indicators of the performance of $K P U$ in increasing public participation.

\section{A. Input}

Mahsun (2012: 77) argues that "Input means everything needed for the implementation of activity able to provide the output. This indicator measures resources including budget (fund), human resources, equipment, materials, and other inputs for the implementation of activity". The result indicated that performance indicator in terms of input has not been optimal due to low educational level of the human resources of $K P U$. This is not in line with Dessler's (2010: 329), "the measurement of performance includes these indicator knowledge on the job". Practical and technical skills and information needed for the job. In addition, according Mahmudi (2010: 20), "one of factors that affect the performance is personal/individual factor, consisting of knowledge, skill, capability, self-confidence, motivation, and commitment of every individuals". Therefore, human resources is influential for the performance of $K P U$ in the holding of local elections in addition to budget and facilities and infrastructures.

In order to overcome the issue, $K P U$ should have been more intense to hold technical and functional trainings comprehensively in each districts considering the large area of Blitar regency. In addition, it is necessary to have recruitment of the member of Organizing Agency transparently by making clear of the reward thus would intrigue qualified people to join.

\section{B. Process}

Mahsun (2012: 77) argues that "process explain how organization formulates criteria for the activity in terms of speed, precision, and accuracy of its implementation". The most dominant rule in process is how efficient and economical the activity is in terms of its implementation and timing. Activities in the election of Regent and Vice-Regent of Blitar are including promotion, establishment of Organizing Agency, updating the DPT, candidacy, campaign, voting and counting, deciding of elected candidate and inauguration.

Targets for promotion include components of public in general; beginner voters such as adolescent, teenagers, and students; public figures and/or traditional leaders; groups of mass media; political parties; social institutions; religious organizations; traditional institutions; government agencies; and/or voters with special needs. The method includes face-toface communication of direct meetings such as discussion, seminary, workshop, voter education, lecture, and simulation. Communication and information delivery via mass media are in form of text, pictures, audiovisual, website, advertisement talk show and candidates debate.

$K P U$ of Blitar regency formulates the activities by considering the accuracy, economization, and efficiency. Accuracy means how accurate its implementation is. Economization means that the activities spend less than the predetermined budget and time. Efficiency of the activities means that there should more outcomes gained by using available resources.

Result of this research showed that performance of $K P U$ of Blitar regency measured by indicator of process was not optimal, since the implementation failed to achieve the target in terms of promotion and other activities. This is not in line with Sedarmayanti's (2011: 196-197) argument that "organizational performance is measured from aspects such as internal business operation to ensure that all activities are in harmony to achieve the organizational purposes and objectives as stated in the strategic plan, and to continuously improve the efficiency and effectiveness of the operation". In addition, it is also not in line with what Rummler and Brachein Sudarmanto, (2009: 7) suggest that in terms of performance, "the process that generate products or services is affected by its purpose, design, and management", thus accuracy of the implementation is influential for the performance of $K P U$ in local elections, especially in promotion since it shall affect whether the public participation will be high or low.

In order to overcome the issue, $K P U$ should have been more intense to hold promotion to the whole society comprehensively in all districts due to the large area of Blitar regency so that everyone would be familiar with local elections. In addition, promotion should be delivered more attractively and adapted to the characteristics of public, such as via Ludruk, Wayang, etc.

\section{Output}

Mahsun (2012: 77) argues that "output means nothing that is expected to be directly achieved from the activity both in physical and nonphysical form". This indicator measures the output produced in activity according to the plan. This indicator is to find out what products has been generated by $K P U$ of Blitar regency to determine whether the activities scheduled were implemented according to the plan or not. Performance of $K P U$ of Blitar regency as measured by output indicator can be concluded as administratively proper and systematic and the activities ran as scheduled. The products are Decisions of $K P U$ of Blitar regency, by which can be used as productivity reference for performance of $K P U$ of Blitar regency in holding local elections in Blitar regency. 
This is in inline with Wirawan's (2012: 53) argument that "product in form of goods and services can be calculated in terms of the quality and quantity". In addition, this is also in line with what Jerry Harbourin Sudarmanto, (2009: 13) suggests that "performance can be measured in terms of its productivity aspect", which in this context is the capability to produce goods and services in the activity of local elections.

\section{Outcomes}

Mahsun (2012: 77) argues that "outcome means everything that reflects the functioning output of the activity for medium term (direct effect)". Measurement of this outcome indicator is often confused with output indicator. Outcome indicator is more important than just output indicator. Outcomes define the attainment of higher result that may include the interests of many parties. With outcome indicator, KPU of Blitar regency can determine whether what has been achieved as output can really be used properly and be great benefit to people.

Performance of $K P U$ of Blitar regency as measured with outcome indicator was not optimal in reducing the absentee rate of public participation and in selection of candidates for local elections. It shows that there are two types of public participation according to typology by Pretty J. in Karianga, (2011: 223),"passive and manipulative participation and intensive participation". Characteristics of public with passive and manipulative participation is seen in organizer of DPT of 2015 Blitar regency local elections, in which people receive information of what is and has happened, one-way announcement from project implementer does not consider public responses as the target of program, the information limited only for professional outside of target group.

Characteristics of public with intensive participation are that public give their value and provide service in order to gain intensive reward, although not being involved in learning or experiment processes by members and Secretariat of $K P U$, and public have no chance to contribute in the activities after the intensive stopped.

In order to overcome the issue, $K P U$ and the candidates of Regent and Vice-Regent should have been more intense to promote and campaign directly to whole society as an effort to stimulate public participation, and to introduce to public about their future figure of leaders.

\section{E. Benefit}

Mahsun (2012: 77) argues that "benefit means anything related to final objectives of the implementation of activity". Benefit indicator describes the advantages gained from outcome indicator. In relation with final objective of the implementation of 2015 Blitar regency local elections, the benefit gained based on the result of local elections would be felt by public and organizations. The benefit received should be for medium and long term. The benefit indicator shows that the implementation of local elections is in accordance with the expectation that it is accomplished and functioning optimally, appropriate in both time and location.
Result showed that, in terms of benefit indicator, the local elections provide benefit to organizations and public in medium term, but not yet in long term. It is due to the elected Local Leader is still in the first year of service thus can not yet truly accomplish the vision and mission. It is in line with Sedarmayanti (2011: 196-197) who suggest, "in terms of the measurement of performance via aspects of customer satisfaction, employee satisfaction, and community and stakeholder satisfaction, that there is satisfaction of both public and organization on the implementation of local election, considering the benefit they receive".

\section{F. Impact}

Mahsun (2012: 77) argues that "impact means any effects or influences both in terms of positive and negative". Impact of the implementation of local elections in general can be measured by what public feel as the object of local elections. As for organizations, both $K P U$ of Blitar regency and Local Government of Blitar regency, there was no impact because the local elections is the main program of $K P U$ that should be implemented according to the regulation and procedure.

Result showed that, in terms of impact indicator, implementation of local elections has negative impacts on most of society, especially the economically disadvantaged, in which time is very important for them and influential to their income. It is not in line with Bernadin'sin Sudarmanto, (2009: 12) argument suggesting that "one of dimensions to measure performance is interpersonal impact, which is individual capability to improve self esteem, good will and cooperation among society". In addition, it is also not in line with Sedarmayanti (2011: 196-197) who suggest, "in terms of the measurement of performance via satisfaction of community and shareholders/stakeholders", that the activities local elections interact with various parties along with their own interests, thus local elections was designed to accommodate those different interests.

In order to overcome the issue, $K P U$ should have had initiative for the implementation of local elections by providing mobile polling station to accommodate people who work out of office hours, such as TPS on the market or polling station for farmers.

\section{CONCLUSIONS AND RECOMMENDATIONS}

\section{A. Conclusions}

Performance of $K P U$ in increasing public participation in 2015 Local Election in Blitar regency, East Java province was not optimal, which can be seen in indicators as follow:

1. In input indicator, there are available fund and facilities and infrastructures to support $K P U$ of Blitar regency, but not optimal in terms of human resources, specifically recruitment of the members of Organizing Body, due to lack of people with high education in Blitar regency.

2. In process indicator, $K P U$ of Blitar regency has perform its duty economically and efficiently, but not optimal in 
the accuracy, speed, and punctuality of the schedule due to the promotion was not implemented comprehensively to all districts.

3. In outcome indicator, $K P U$ of Blitar regency was still unable to reduce the absentee rate and thus considered to be unable to increase the public participation through programs as implemented in the 2015 Local Elections of Blitar regency.

4. In impact indicator, the performance of $K P U$ of Blitar regency in Local Elections has impact on the economically disadvantaged society, in which the election took their time of making a living.

\section{B. Recommendations}

In relation with the conclusion above, authors would like to suggest several recommendations for $K P U$ to overcome the problems. It is necessary to take these steps for the solutions: first, $K P U$ of Blitar regency should be more intense to organize technical and functional trainings comprehensively in every districts, considering the large area of Blitar regency, to have recruitment of the member of Organizing Agency transparently by making clear of the reward thus would intrigue qualified people to join. Second, KPU of Blitar regency should deliver the promotion more attractively and according to public characteristic, such as via Ludruk, Wayang, etc., convene focus group discussion that involve all elements of society to accommodate the problems and look for solutions that is acceptable by whole society. Third, $K P U$ of Blitar regency and the candidates of Regent and Vice-Regent should be more intense to promote and campaign directly to whole society as an effort to stimulate public participation and to introduce to public about their future figure of leaders, to evaluate the programs of $K P U$ in each phase of elections, whether Presidential, Governor and Vice Governor, Regent and Vice Regent, and Legislative Elections. Fourth $K P U$ should have initiative for the implementation of local elections by providing mobile polling station to accommodate people who work out of office hours, such as TPS on the market or polling station for farmers.

\section{REFERENCES}

[1] Dessler, Gary. 2010. Manajemen sumber daya manusia, Penerjemah: Eli Tanya. Jakarta, Index.

[2] Karianga, Hendra. 2011. Partisipasi masyarakat dalam mengelola keuangan daerah (perspektif hukum dan demokrasi). Bandung, PT. Alumni.

[3] Mahmudi, 2010. Manajemen kinerja sektor publik. Sekolah Tinggi Ilmu Manajemen YKPN.

[4] Mahsun, Mohammad. 2012.Pengukuran kinerja sektor publik. Yogyakarta, BPFE Yogyakarta.

[5] Miles, Mathew B. Dan A. Meichael Huberman. 1992.Analisis data kualitatif, Alih bahasa : Tjetjep Rohendi Effendi, Jakarta : UI Press

[6] Moleong, Lexy J. 2012. Metode penelitian kualitatif. Bandung, Remaja Rosdakarya.

[7] Sedarmayanti. 2011. Manajemen sumber daya manusia: reformasi birokrasi dan manajemen pegawai negeri sipil. Bandung, Refika Aditama.

[8] Sudarmanto. 2009. Kinerja dan pengembangan kompetensi. Yogyakarta, Pustaka Belajar.

[9] Sugiyono. 2013. Metode pendidikan penelitian. Bandung, Alfabeta.

[10] Wirawan. 2012. Evaluasi kinerja sumber daya manusia (teori, aplikasi, dan penelitian). Jakarta, Salemba Empat.

\section{LAW AND REGULATIONS}

The 1945 Constitution of the Republic of Indonesia

[11] Law No. 9 of 2015 on Second Amendment of Law No. 23 of 2014 on Local Government

[13]Law No. 8 of 2015 on Amendment of Law No. 1 of 2015 on Decision of Government Regulation in Lieu of Law No. 1 of 2014 on Governor, Regent, and Mayoral Elections as Law

[14]Law No. 15 of 2011 on The Organizer of General Elections. 